\title{
Crystalline surface protein of Peptostreptococcus anaerobius
}

\author{
Anja Kotiranta, ${ }^{1}$ Markus Haapasalo, ${ }^{1}$ Kari Lounatmaa ${ }^{2}$ and Kirsti Kari ${ }^{3}$
}

Author for correspondence: Markus Haapasalo. Tel: +358 047351 . Fax: +358 0414272.

Departments of Cariology ${ }^{1}$ and Electron Microscopy? Research Laboratory of the Institute of Dentistry ${ }^{3}$, University of Helsinki, PB 41, SF-00014 Helsinki, Finland
The surface ultrastructure of three anaerobic Gram-positive cocci frequently encountered in oral infections, Peptostreptococcus micros, P. magnus and $P$. anaerobius, was studied. The type strains of P. micros (DSM 20468) and $P$. anaerobius (ATCC 27337), several clinical isolates of both species and the type strain of P. magnus (DSM 20470) were included. Thin-sectioned celis studied by electron microscopy revealed a homogeneous layer outside the peptidoglycan layer in $\boldsymbol{P}$. anaerobius. In P. micros and $\boldsymbol{P}$. magnus a more amorphous layer was present. No periodic structures were seen in negatively stained whole cells of these three species. However, in freeze-etched cells of $P$. anaerobius a crystalline surface protein layer (S-layer) was detected. No periodicity was seen in any of the P. micros strains or the P. magnus type strain by the methods used, but a periodic pattern was observed in negatively stained specimens of cell wall fragments of sonicated P. anaerobius cells. No capsular material was visible outside the S-layer in P. anaerobius. The cells of the Peptostreptococcus spp. were extracted for $30 \mathrm{~min}$ with detergents and urea. One per cent SDS and $6 \mathrm{M}$ urea both extracted a major $78 \mathrm{kDa}$ protein from all strains of $P$. anaerobius. Extraction of $P$. micros and $P$. magnus cells did not reveal any major protein bands comparable to that of $P$. anaerobius. Surface biotinylation of cells followed by Westem blotting and detection by alkalinephosphatase-conjugated extravidin showed strong staining of the $78 \mathrm{kDa}$ band in $P$. anaerobius, further indicating that this molecule is located on the surface of the cell and is the S-protein. Another protein, of $127 \mathrm{kDa}$, was also detected by surface biotinylation in all P. anaerobius strains. No differences were detected in colony morphology or cell surface structures between the four strains. Isoelectric focusing of the proteins of $P$. anaerobius revealed that the S-proteins of individual strains have different pl values, ranging from 5.3 to 6.9.

Keywords: Peptostreptococcus, S-layer, surface protein, ultrastructure, oral bacteria

\section{INTRODUCTION}

Peptostreptococcus spp. are regularly isolated in infections of the oral region as well as in other parts of the human body (Sugita et al., 1982; Sklavounos et al., 1986; Topiel \& Simon, 1986; Brook et al., 1991; Sundqvist, 1992). Several studies have suggested that Peptostreptococcus spp., especially $P$. magnus, $P$. micros and $P$. anaerobius, may have an important role in the pathogenesis of various infections (Brook \& Walker, 1984; Papasian et al., 1986; Smith et al., 1986a; Brook, 1988; Davies et al., 1988; Hunter \& Chow,

Abbreviations: \%HP, percentage hydrophobicity; NHS-biotin, biotinamidocaproate $\mathrm{N}$-hydroxysuccinimide ester.
1988; Lewis et al., 1989; Panagou et al., 1991; Schenkein et al., 1993). Some studies have also indicated that $P$. micros may be involved in cases of advancing adult periodontitis (Rams et al., 1992; Tew et al., 1985). Apart from their regular isolation as part of the infective flora, relatively little information is available about their potential virulence factors. Mucin degradation by $P$. micros strains isolated from rat intestine (Carlstedt-Duke et al., 1986) and production of a variety of peptidases and hyaluronidases (Tam \& Chan, 1983, 1985; Tam et al., 1987) have been related to their virulence. Collagenase production (Krepel et al., 1991) and expression of protein $\mathrm{L}$, which has the capability to bind to the light chain of immunoglobulins (Kastern et al., 1990), have been reported with some non-oral strains of $P$. magnus. In 
addition to hydrolytic enzymes, bacterial surface properties are also regarded as important for the outcome of the interaction of the bacterial cell with the host's defences (van Steenbergen \& de Graaff, 1983; Absalom, 1988; Lämmler et al., 1989). Messner \& Buckel (1988) reported an S-layer in $P$. asaccharolyticus. Cowan et al. (1992) could not find any evidence of S-layer in $P$. micros in negatively stained samples. We have recently reported a crystalline surface layer in a clinical strain of Peptostreptococcus sp. isolated from purulent ear infection that resembled $P$. magnus (Lounatmaa et al., 1988), but showed some differences from the type strain of $P$. magnus. The present study was undertaken to investigate the surface structure of the three Peptostreptococcus spp. frequently isolated in human infections: P. micros, $P$. magnus and $P$. anaerobius.

\section{METHODS}

Bacterial strains. Peptostreptococcus strains were obtained from reference culture collections (DSM, German Collection of Micro-organisms; ATCC, American Type Culture Collection) or isolated from infections of the oral cavity (Table 1). Identification of the clinical strains was based on Gram staining, oxygen tolerance, profiles of preformed enzymes (RapID ANA II system, Innovative Diagnostic Systems; and API AnIdent system, API Analytab Products) and comparison of the wholecell protein profiles with the reference strains in SDS-PAGE (see below) (Smith et al., 1986b). Pure cultures were preserved in skim milk (Difco) at $-70^{\circ} \mathrm{C}$. The bacterial strains were grown on Brucella horse blood agar plates supplemented with menadione $\left(0.5 \mathrm{mg} \mathrm{l}^{-1}\right)$ and haemin $\left(5 \mathrm{mg} \mathrm{l}^{-1}\right)$, in an anaerobic atmosphere $\left(85 \% \mathrm{~N}_{2}, 10 \% \mathrm{CO}_{2}, 5 \% \mathrm{H}_{2}\right.$; mark 3 Anaerobic

Table 1. Peptostreptococcus strains and their hydrophobicities

\begin{tabular}{|c|c|c|}
\hline Strain & Source & $\% H P( \pm S D)$ \\
\hline \multicolumn{3}{|l|}{ P. anaerobius } \\
\hline ATCC $27377^{\mathbf{T}}$ & ATCC & $35 \cdot 5 \pm 15 \cdot 7$ \\
\hline AHC5715 & NPHI & NT \\
\hline AHC5756 & NPHI & $37 \cdot 0 \pm 8 \cdot 9$ \\
\hline AHC5765 & NPHI & NT \\
\hline AHC5742 & NPHI & $58 \cdot 2 \pm 8 \cdot 9$ \\
\hline AHC5734 & NPHI & $5 \cdot 3 \pm 1 \cdot 7$ \\
\hline \multicolumn{3}{|l|}{ P. micros } \\
\hline DSM $20468^{\mathrm{T}}$ & $\begin{array}{l}\text { DSM (root canal } \\
\text { isolate) }\end{array}$ & $44 \cdot 3 \pm 6 \cdot 9$ \\
\hline MPP-36 & Authors' isolates; & $47 \cdot 3 \pm 4 \cdot 9$ \\
\hline MPP-9 $\}$ & from root canal & $62 \cdot 5 \pm 3 \cdot 1$ \\
\hline T324 & & $50 \cdot 5 \pm 4 \cdot 2$ \\
\hline$T 326^{R}$ & Authors isolates; & $9 \cdot 7 \pm 4 \cdot 2$ \\
\hline T330 & trom periodontal & $58 \cdot 7 \pm 7 \cdot 4$ \\
\hline $\mathrm{T}^{2} 23^{\mathrm{R}}$ & & $13 \cdot 8 \pm 1 \cdot 4$ \\
\hline \multicolumn{3}{|l|}{ P. magnus } \\
\hline DSM $20470^{\mathrm{T}}$ & DSM & NT \\
\hline
\end{tabular}

Abbreviations: ATCC, American Type Culture Collection; DSM, German Collection of Micro-organisms, NPHI, National Public Health Institute of Finland; $T$, type strain; $R$, rough colony variant; NT, not tested.
Work Station, Don Whitley Ltd). Cultures 3-5 d old were used for the experiments.

Electron microscopy. For thin sections, the bacteria were collected from the plates, washed twice with phosphate buffer $(\mathrm{pH} 7 \cdot 3)$ and fixed with $2 \cdot 5 \%(\mathrm{v} / \mathrm{v})$ buffered glutaraldehyde for $2 \mathrm{~h}$ at room temperature. The samples were then washed twice with the same buffer and prepared for electron microscopy as previously described (Lounatmaa, 1985). For negative staining, the cells were collected into phosphate-buffered saline (PBS, $\mathrm{pH} 7 \cdot 2$ ), washed once and stained with $2 \%(\mathrm{w} / \mathrm{v})$ phosphotungstic acid. Cell wall fragments obtained by pulse sonication for $10 \mathrm{~min}$ in an ice bath (30\% duty cycle, output 4; Branson Sonifier model 250 ) were also studied by negative staining. For freeze-etching, the cells were collected from the plates as described above, washed and centrifuged to form a thick suspension and frozen in liquid Freon 22 cooled by liquid nitrogen. The fracturing, in a Balzers freeze-etching unit BAF $400 \mathrm{~T}$, was performed at $-100^{\circ} \mathrm{C}$ and the platinum shadowing after 1 min etching at an angle of 40 degrees (Lounatmaa, 1985). The electron micrographs were taken with JEM-1200EX and $100 \mathrm{CX}$ transmission electron microscopes at $60 \mathrm{kV}$.

Hydrophobicity assay. Cell surface hydrophobicities were measured as previously described (Rosenberg et al., 1980; Haapasalo et al., 1990). Cells were grown for $4 \mathrm{~d}$ on supplemented Brucella blood agar plates and collected in PBS. Cell suspensions were adjusted to $\mathrm{OD}_{450} 0.5$ in PBS (Cary 210 spectrophotometer). n-Hexadecane $(200 \mu \mathrm{l}$; Sigma) was thoroughly mixed with $3 \mathrm{ml}$ of the cell suspension for $90 \mathrm{~s}$ with a Vortex mixer (Scientific Industries). Cells mixed in PBS without hexadecane were used as controls. The percentage hydrophobicity (\%HP) was calculated as the change in the optical density of the PBS phase before and 15 min after mixing according to the formula

$\% \mathrm{HP}=\frac{\left(H_{\mathrm{i}}-H_{\mathrm{e}}\right)-\left(C_{\mathrm{i}}-C_{\mathrm{e}}\right)}{H_{\mathrm{i}}} \times 100$

where $H_{1}$ is the initial optical density of the PBS phase before mixing (hexadecane tube), $H_{\mathrm{e}}$ the optical density after mixing, and $C_{1}$ and $C_{\mathrm{e}}$ are the corresponding values in the control tubes. The higher the value, the more hydrophobic the cells. Two samples of the same bacterial cell suspensions were used for each measurement and all strains were tested at least twice, using new cultures each time.

Extraction of Peptostreptococcus surface proteins. Freshly cultured bacterial cells were washed twice in $20 \mathrm{mM}$ Tris buffer ( $\mathrm{pH} \mathrm{8.0)} \mathrm{and} \mathrm{incubated} \mathrm{in} \mathrm{the} \mathrm{same} \mathrm{buffer} \mathrm{in} \mathrm{the} \mathrm{presence} \mathrm{of} 6 \mathrm{M}$ urea or one of the following detergents: $0.1 \%$ and $1.0 \%$ SDS (Sigma) $; 0 \cdot 1 \%, 1 \cdot 0 \%$ and $2 \cdot 1 \%$ deoxycholate (Sigma). The cells were gently shaken at room temperature for $30 \mathrm{~min}$ with the detergents or urea and centrifuged $(16000 \mathrm{~g}, 10 \mathrm{~min})$. The supernatant was analysed by protein electrophoresis as described below.

Gel electrophoresis and surface biotinylation. SDS-PAGE was performed in $10 \%(\mathrm{w} / \mathrm{v})$ geis at $200 \mathrm{~V}$ as described by Laemmli (1970) (Mini Protean II, Bio-Rad). Molecular masses of the polypeptides were determined by comparison with standards (Bio-Rad). In some samples whole cells were boiled in sample buffer for 5 or $15 \mathrm{~min}$. The supernatant obtained after centrifugation was used for the electrophoresis. Surface biotinylation was performed as described by Dooley \& Trust (1988). The cells ( $50 \mu \mathrm{l}$ cells in $1 \mathrm{ml}$ PBS) were incubated for $2 \mathrm{~min}$ at room temperature with $2 \mu \mathrm{l}$ NHS-biotin (biotinamidocaproate $N$-hydroxysuccinimide ester, $50 \mathrm{mg}$ in $1 \mathrm{ml}$ dry DMSO; Sigma) that was diluted 1:20 in PBS. The reaction was 
stopped with Tris buffer ( $\mathrm{pH} 7 \cdot 5$, final concentration $100 \mathrm{mM})$, and the cells were washed twice with $50 \mathrm{mM}$ Tris buffer (pH 7.5). Sample preparation and electrophoresis were performed as above. Polypeptides were transferred to nitrocellulose membrane (Bio-Rad) in Tris/glycine $\left(5.8 \mathrm{~g} \mathrm{l}^{-1} / 2.9 \mathrm{~g} \mathrm{l}^{-1}\right)$ blotting buffer with $20 \%(\mathrm{v} / \mathrm{v})$ methanol for $1 \mathrm{~h}$ at $0.8 \mathrm{~mA} \mathrm{~cm}$ (Nova-Blot, Pharmacia LKB Biotechnology). The membranes were blocked with $3 \%(\mathrm{w} / \mathrm{v})$ bovine serum albumin (BSA) in Tris-buffered saline (TBS; $20 \mathrm{mM}$ Tris, $0.5 \mathrm{M} \mathrm{NaCl}, \mathrm{pH} 7.5$ ) for $1 \mathrm{~h}$. The membranes were incubated with alkaline-phosphataselabelled extravidin (1:20000 in 1\% BSA in TBS; Sigma) for $1 \mathrm{~h}$, washed and stained. The colour-developing substrates were $44 \mu \mathrm{l}$ nitroblue tetrazolium (Sigma) $\left(75 \mathrm{mg} \mathrm{ml}^{-1}\right.$ in $75 \%, \mathrm{v} / \mathrm{v}$, dimethylformamide) and $33 \mu \mathrm{l}$ 5-bromo-4-chloro-3-indolyl phosphate (Sigma) $\left(50 \mathrm{mg} \mathrm{ml}^{-1}\right.$ in dimethylformamide) in $10 \mathrm{ml}$ substrate buffer $(0.1 \mathrm{M}$ Tris, $0.1 \mathrm{M} \mathrm{NaCl}, 50 \mathrm{mM} \mathrm{MgCl}$, $\mathrm{pH} 9 \cdot 5)$.

Two-dimensional PAGE. Isoelectric focusing (IEF) of $P$. anaerobius proteins was performed by using a Multiphor II electrophoretic unit (Pharmacia) using precast Immobiline Drystrips (Pharmacia) according to the manufacturer's directions. Briefly, $P$. anaerobius cells were disrupted in lysis buffer (27 $\mathrm{g}$ urea, $1 \mathrm{ml}$ Triton X-100, $1 \mathrm{ml}$ 2-mercaptoethanol, $1 \mathrm{ml}$ Pharmalyte 3-10 and $70 \mathrm{mg}$ phenylmethylsulfonyl fluoride in $50 \mathrm{ml}$ distilled water) and dissolved in sample buffer $(24 \mathrm{~g}$ urea, $1 \mathrm{ml}$ 2-mercaptoethanol, $1 \mathrm{ml}$ Pharmalyte 3-10, $0.25 \mathrm{ml}$ Triton X-100 and a few grains of bromophenol blue in $50 \mathrm{ml}$ distilled water). A $50 \mu$ l portion of each sample was applied at the anode end of the rehydrated Immobiline Drystrips ( $\mathrm{pH} 4 \cdot 0-7 \cdot 0$ ) using sample cups. Sample cups and strips were covered with silicone oil and IEF was carried out on a cooling plate as a stepwise run giving $35 \mathrm{kV}$ h. After running, the strips were incubated for $2 \times 10 \mathrm{~min}$ in equilibrating solution $(50 \mathrm{mM}$ Tris buffer, $\mathrm{pH} 6.8$, urea $360 \mathrm{~g} \mathrm{l}^{-1}$, glycerol $300 \mathrm{ml} \mathrm{l}^{-1}$ and SDS $\left.10 \mathrm{~g} \mathrm{l}^{-1}\right)$. For the second dimension the strips were embedded into the stacking gel and SDS-PAGE was run in a 8-18\% (w/v) gradient gel (ExcelGel SDS; Pharmacia) according to manufacturer's directions. The proteins were stained with Coomassie blue and the $\mathrm{pI}$ was determined by comparison with standards (high pI kit; Pharmacia).

\section{RESULTS}

Cell surface ultrastructure of $P$. micros, $P$. magnus and $P$. anaerobius was studied by electron microscopy. A homogeneous outer layer about $10 \mathrm{~nm}$ thick outside the peptidoglycan layer was present in $P$. anaerobius. In $P$. micros and $P$. magnus (not shown) a more amorphous layer was seen (Fig. 1). Negative staining of whole cells revealed no periodic structures in $P$. anaerobius. However, when cells of $P$. anaerobius were disrupted by sonication, cell wall fragments with periodic structures were detectable in negatively stained samples (Fig. 2). Freeze-etching of whole cells followed by platinum and carbon shadowing clearly showed a periodic crystalline surface layer in $P$. anaerobius (Fig. 3a, b). The width of the repeating unit was $12 \mathrm{~nm}$. None of the electron microscopic methods used in this study revealed any periodic structures in $P$. micros strains or in the type strain of $P$. magnus.

Whole cells of $P$. anaerobius ATCC 27337 were extracted with $0 \cdot 1$ and $1 \%$ SDS, $0 \cdot 1-2 \cdot 1 \%$ deoxycholate and $6 \mathrm{M}$ urea to identify the probable S-layer protein. A major $78 \mathrm{kDa}$ band was obtained with $6 \mathrm{M}$ urea and $1 \%$ SDS
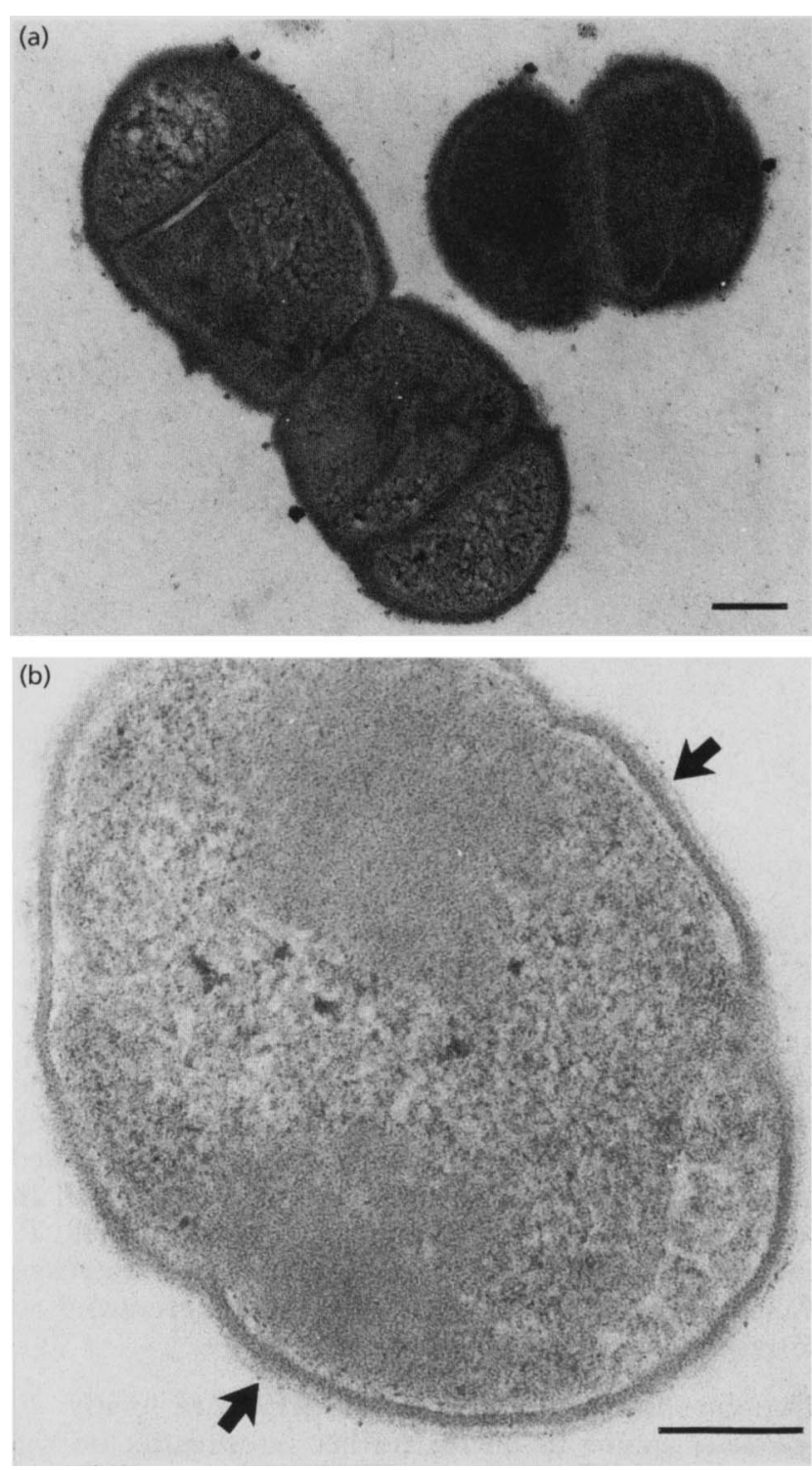

Fig. 1. Thin-sectioned cells of $P$. micros DSM 20468 (a) and $P$. anaerobius ATCC 27337 (b). A thin layer of polymeric substance outside the peptidoglucan covers the cells of $P$. anaerobius (arrows). The bars in these and subsequent micrographs represent $0.1 \mu \mathrm{m}$.

(Fig. 4, lanes 1 and 2), but not with $0 \cdot 1 \%$ SDS or deoxycholate. The $78 \mathrm{kDa}$ band also appeared in SDSPAGE when whole cells were boiled in sample buffer containing $0.7 \%$ SDS and the supernatants were examined. There were differences in the protein profiles of different $P$. anaerobius strains, but the $78 \mathrm{kDa}$ protein was present in every strain as the major protein (Fig. 5). Urea and detergent extraction of P. micros (Fig. 6) and P. magnus (not shown) followed by SDS-PAGE revealed no corresponding dominant protein band.

Whole cells of the three Peptostreptococcus species were biotinylated for a short period with NHS-biotin. Immediately after biotinylation, Tris buffer was added to 


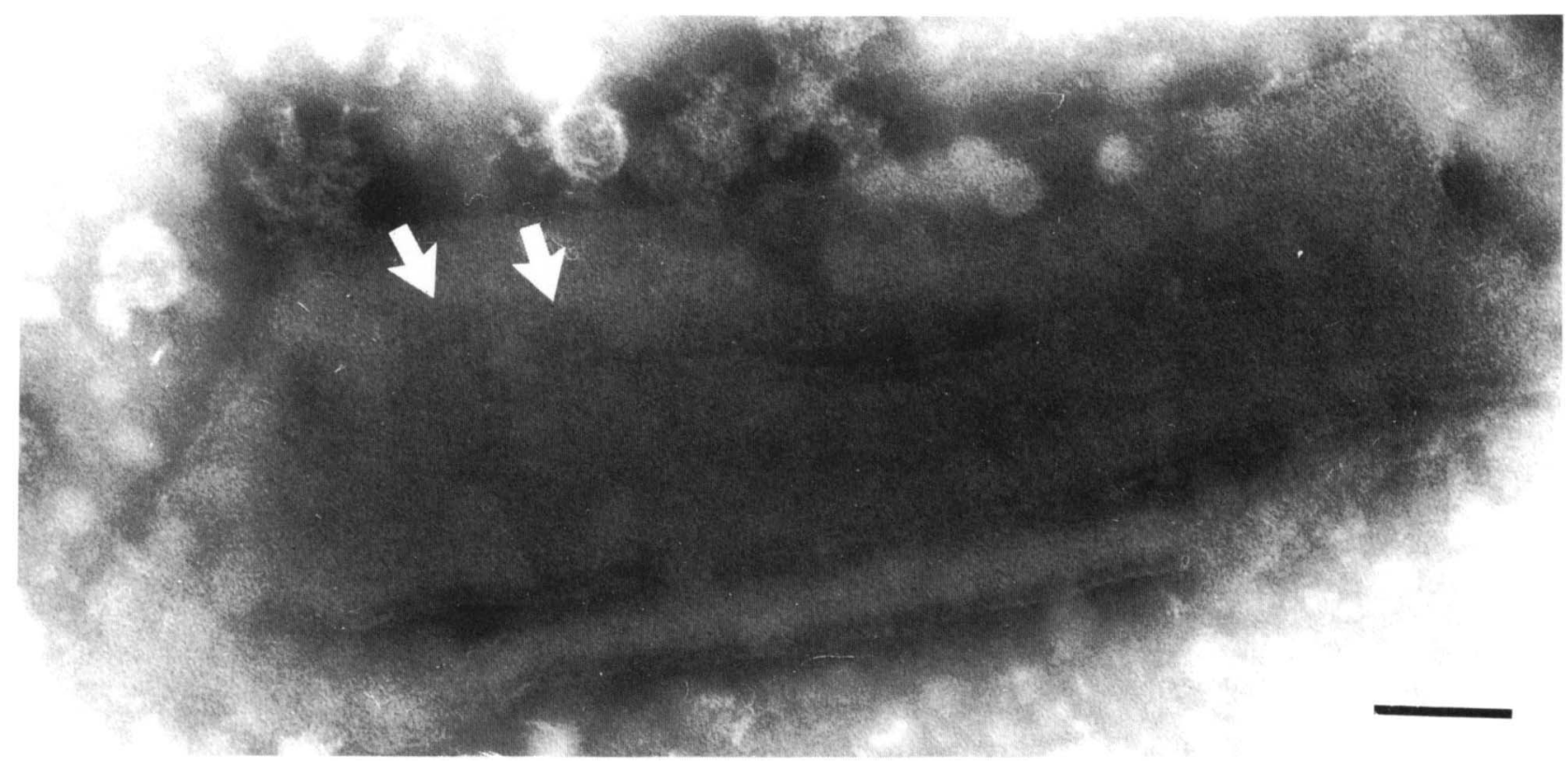

Fig. 2. Negative staining of a cell wall fragment obtained by sonication of $P$. anaerobius ATCC 27337. Cell-surface periodicity can be seen (arrows).

bind all unbound biotin. SDS-PAGE of the biotinylated cells followed by Western blotting and detection by alkaline-phosphatase-conjugated extravidin revealed strong staining of the $78 \mathrm{kDa}$ band in $P$. anaerobius. In addition, a sharp $127 \mathrm{kDa}$ band appeared in all $P$. anaerobius strains (Fig. 7). Western blotting of biotinylated $P$. micros (Fig. 7) and $P$. magnus (not shown) revealed no corresponding major protein band.

Two-dimensional PAGE was performed with $P$. anaerobius strains to obtain further information on the characteristics of the crystalline surface protein. In all four strains studied, the S-protein appeared as a row of dots, probably because of deamination, typically seen in IEF of bacterial proteins (Fig. 8a, b). The pI ranges of the Sproteins differed between strains: the $\mathrm{pI}$ of the S-protein of $P$. anaerobius AHC5734 and AHC5742 was between 5.3 and 5.7 (5.4-5.7 and 5.3-5.6 respectively), while the corresponding values for strains ATCC 27377 and AHC5756 were $6 \cdot 1-6.6$ and $6 \cdot 7-6 \cdot 9$. The pI range for each strain was stable between repeated runs.

The hydrophobicity of $P$. micros (a total of seven strains incuding two rough colonial variants) and $P$. anaerobius (four strains) was measured by the hexadecane method. The $\% \mathrm{HP}$ of all P. micros strains with a smooth colony type ranged from 44.3 to 62.5 , whereas the two rough strains were hydrophilic (\% $\%$ P $9 \cdot 7$ and $13 \cdot 8$ ) (Table 1). The \%HP of three of the $P$. anaerobius strains was 35.5-58.2; however, the fourth strain tested, AHC 5734, was very hydrophilic (\%HP 5.3) (Table 1). No differences could be detected in colony morphology or in electron microscopic appearance between the hydrophilic and hydrophobic strains of $P$. anaerobius.

\section{DISCUSSION}

The present study is the first description of a crystalline surface protein (S-layer) on Peptostreptococcus anaerobius. We were unable to see cells with a continuous S-layer in the freeze-etched specimens. The periodicity of the Slayer was not very clear at all sites even in freeze-etched specimens. It is therefore possible that a thin layer of some other polymeric material covers the S-protein. This could partly explain the difficulty in observing, the S-layer in negatively stained specimens, when material occupying/ covering the possible pits in the S-protein sheet may leave no physical room for the stain. It is, however, also possible that the three-dimensional structure of the outer surface of the S-layer is unfavourable for negative staining. No periodic structures were detected on $P$. micros and $P$. magnus. Lounatmaa et al. (1988) reported an S-layer on a Peptostreptococcus sp. strain AHC5155 that resembled $P$. magnus. However, close comparison with the type strain of $P$. magnus in this study showed that strain AHC5155 cannot be identified as $P$. magnus. Classification of species in the genus Peptostreptococcus has recently undergone several changes and many new species have been established (Ezaki et al., 1983; Li et al., 1992). So far we have not been able to identify strain AHC5155 as any of the currently recognized species.

A $78 \mathrm{kDa}$ major protein was detected in all $P$. anaerobius strains. This finding is in accordance with the results of Smith et al. (1986b). Biotinylation of bacteria in suspension for a short period with NHS-biotin followed by the addition of Tris buffer to bind all unbound biotin to the amine groups of the buffer labels proteins exposed to the surface of the bacterial cells (Dooley \& Trust, 1988). 

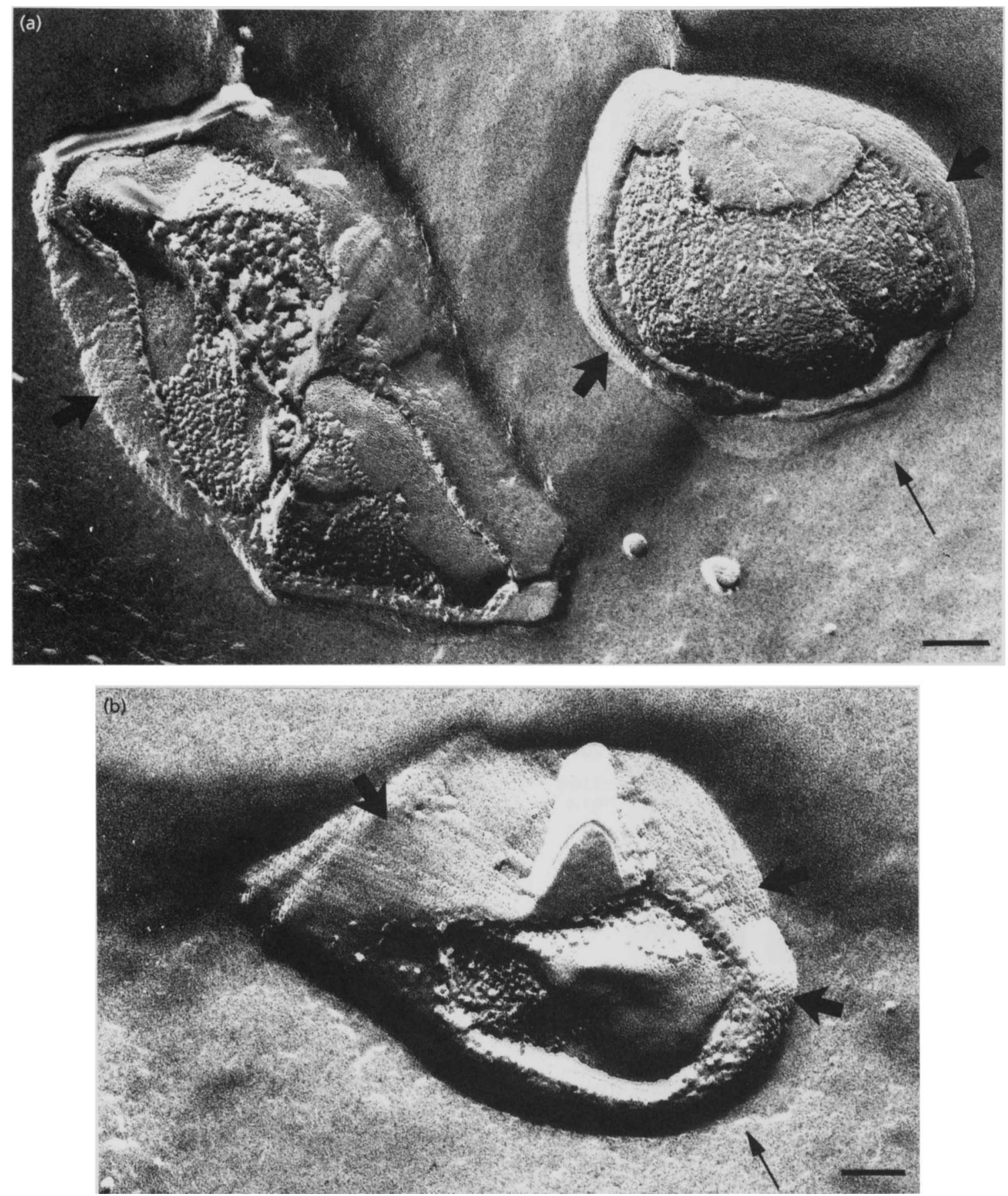

Fig. 3. (a, b). Freeze-etched and metal-shadowed cells of $P$. anaerobius ATCC 27337 . The periodicity of the crystalline surface layer on the cells can be seen (thick arrows). Direction of shadowing is indicated by thin arrows.

Two proteins stained strongly after blotting in all $P$. anaerobius strains, a major $78 \mathrm{kDa}$ and a $127 \mathrm{kDa}$ band. A $95 \mathrm{kDa}$ band and several lower molecular mass proteins that stained in SDS-PAGE did not stain at all in Western blotting after surface biotinylation (Figs 4, 5 and 7). This further indicates that the $78 \mathrm{kDa}$ and the $127 \mathrm{kDa}$ molecules are located on the surface of the cell. It is obvious that, as the major protein, the $78 \mathrm{kDa}$ protein rather than the $127 \mathrm{kDa}$ protein is the S-protein. The molecular mass difference of the two proteins suggests that the $127 \mathrm{kDa}$ protein is not a dimer of the $78 \mathrm{kDa}$ protein. However, the relationship of these two proteins on the surface of $P$. anaerobius remains unclear. Biotinylation of $P$. micros revealed no major protein band in Western blots. This is in line with the electron microscopic examination, which gave no indication of a 


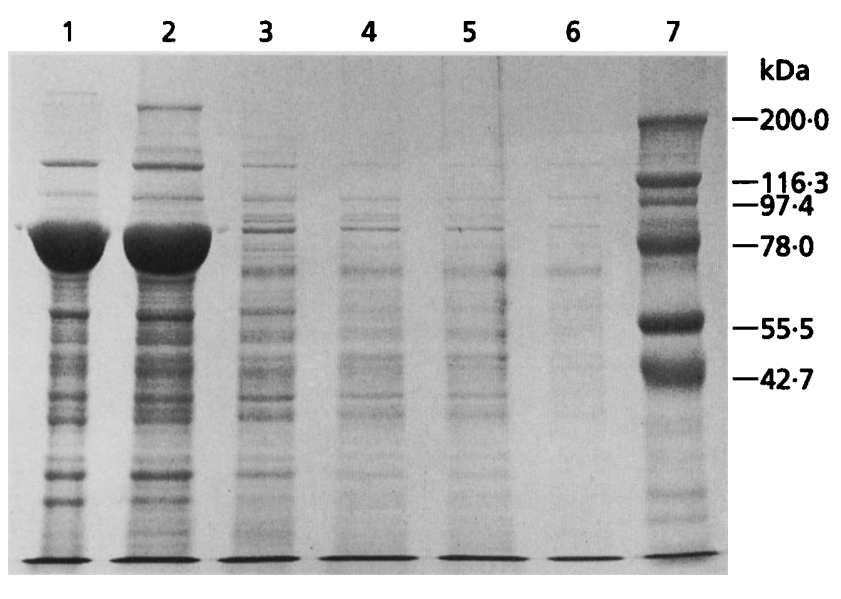

Fig. 4. SDS-PAGE analysis of cell-surface proteins of $P$. anaerobius ATCC 27337. Whole cells were extracted with urea and different detergents for $30 \mathrm{~min}$. Lanes: 1, $6 \mathrm{M}$ urea extract; 2 , $1 \%$ SDS extract; $3,0.1 \%$ SDS extract; $4,2.1 \%$ deoxycholate extract; $5,1 \%$ deoxycholate extract; $6,0.1 \%$ deoxycholate extract; 7 , standard proteins (ovalbumin, $42.7 \mathrm{kDa}$; glutamate dehydrogenase, $\quad 55.5 \mathrm{kDa}$; ovotransferrin, $\quad 76-78 \mathrm{kDa}$; phosphorylase $b, 97.4 \mathrm{kDa} ; \beta$-galactosidase, $116.3 \mathrm{kDa}$; myosin, $200 \mathrm{kDa}$ ).

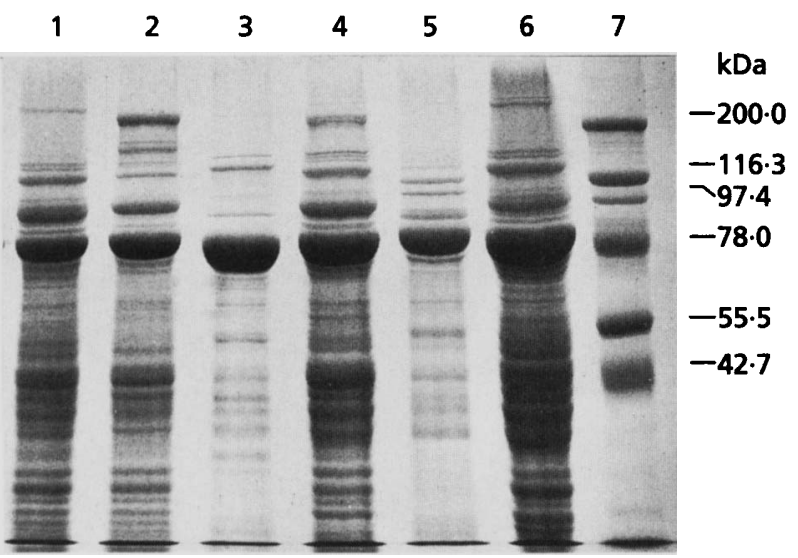

Fig. 5. Whole-cell protein profiles of $P$. anaerobius strains in SDS-PAGE. Lanes: 1, AHC5734; 2, AHC5742; 3, AHC5765; 4, AHC5756; 5, AHC5715; 6, ATCC 27337; 7, standard proteins (same as Fig. 4). The $78 \mathrm{kDa}$ protein is a major protein in all strains.

presence of an S-protein in P. micros but suggested the presence of a capsule.

Our earlier studies have indicated that S-layers have a major effect on the hydrophobicity of the cells and that the variation between different strains of the same species with an S-layer is considerably smaller than in species with no S-layer (Haapasalo et al., 1990). This is obviously not the case with $P$. anaerobius, as one of four $P$. anaerobius strains studied was very hydrophilic while the others were relatively hydrophobic. Recently van Dalen et al. (1993) reported that $P$. micros strains with a rough colony type

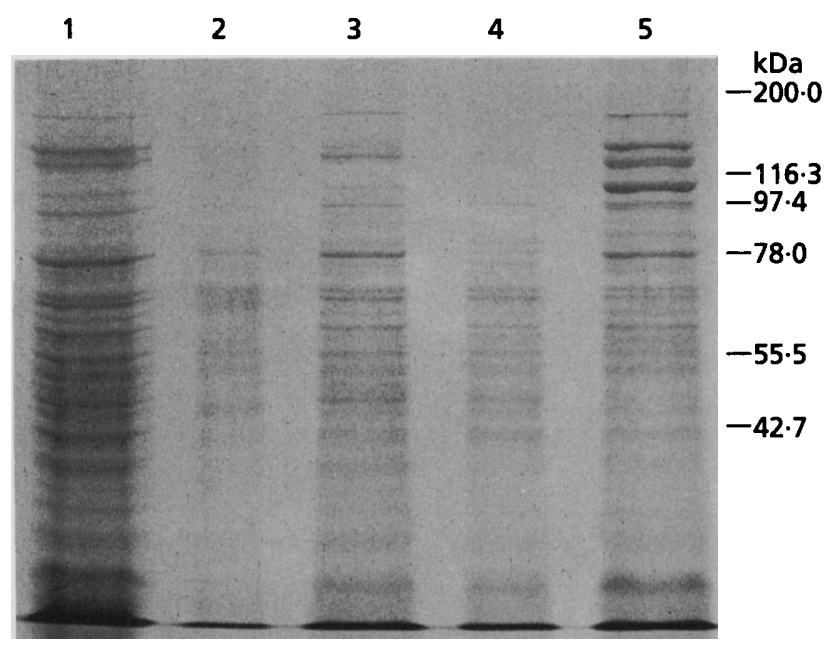

Fig. 6. SDS-PAGE analysis of whole-cell proteins and urea or detergent extracts of $\boldsymbol{P}$. micros DSM 20468 (lanes 1-4: lane 1, whole cells; lane 2, $6 \mathrm{M}$ urea extract; lane 3, 1\% SDS extract; lane 4, 0.1\% SDS extract) and P. micros MPP-36 (lane 5: whole cells).

are hydrophilic as compared to strains with a smooth colony type. This was also confirmed in the present study. However, in the case of $P$. anaerobius we were unable to find any differences in colony morphology or ultrastructure between the hydrophilic and hydrophobic strains. An S-protein of the same molecular size was found in all strains; however, the $\mathrm{pI}$ values of the Sproteins of $P$. anaerobius strains were different. Strains AHC5734 and AHC5742, the most hydrophilic and the most hydrophobic strain, had clearly lower $\mathrm{pI}$ values (5.3-5.7) than strains AHC5756 and ATCC 27377 (6.1-6.9) (Fig. 8a, b). The biological relevance of the differences in pI of the S-proteins remains unclear.

Crystalline surface protein layers are present in several oral bacteria, in both Gram-negative and Gram-positive species (Messner \& Sleytr, 1992; Lounatmaa et al., 1993), and bacteria with S-layers are regularly present in oral infections. The role of the S-layer in virulence and microbial ecology for the majority of species possessing an S-layer is not known. In the case of the fish pathogen Aeromonas salmonicida it has been shown that only strains with an S-layer are virulent (Trust \& Kay, 1992). Blaser et al. (1988) reported that the S-layer of Campylobacter fetus may render the cell resistant to phagocytosis. We have shown that the S-layers of bacteria from the human oral cavity seem to be of major importance in determining the cell surface hydrophobicity (Haapasalo et al., 1990), which in turn plays a role in bacteria-leucocyte interaction (Absalom, 1988). We have also studied the nonopsonophagocytosis of a new oral anaerobe, Eubacterium yurii, of which all three subspecies possess an S-layer. Only one subspecies, subsp. margaretiae, was resistant to phagocytosis, while the two others were readily ingested by the leucocytes (Kerosuo et al., 1993). The importance and function of the S-layers of the Peptostreptococcus species 


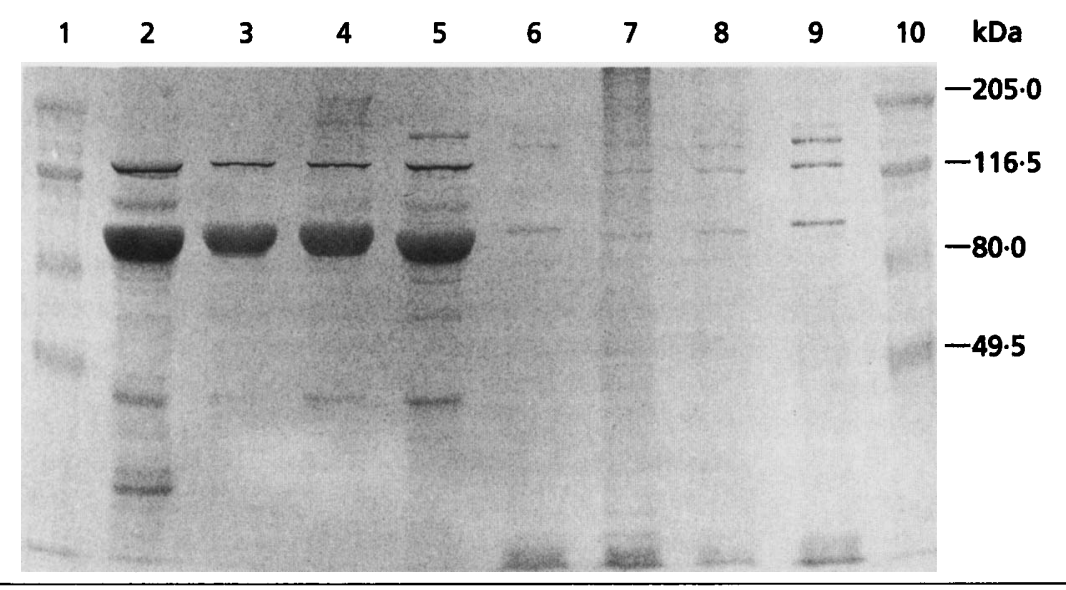

Fig. 7. Western blotting of biotinylated cell surface proteins of $P$. anaerobius and $P$. micros strains. Lanes: 1 and 10, prestained standard proteins (ovalbumin, $49.5 \mathrm{kDa}$; bovine serum albumin, $80 \mathrm{kDa}$; $\beta$-galactosidase, $\quad 116.5 \mathrm{kDa}$; myosin, 20.5 kDa); 2, $P$. anaerobius ATCC 27337; 3, $P$. anaerobius AHC5734; 4, $P$. anaerobius AHC5742; 5, P. anaerobius AHC5756; 6. P. micros DSM 20468; 7, P. micros 1-60; 8, P. micros MPP-9; 9, P. micros MPP-36. Strong staining of a major $78 \mathrm{kDa}$ band and a minor $127 \mathrm{kDa}$ band is clearly seen in all $P$. anaerobius strains. Corresponding staining cannot be detected in $P$. micros strains.

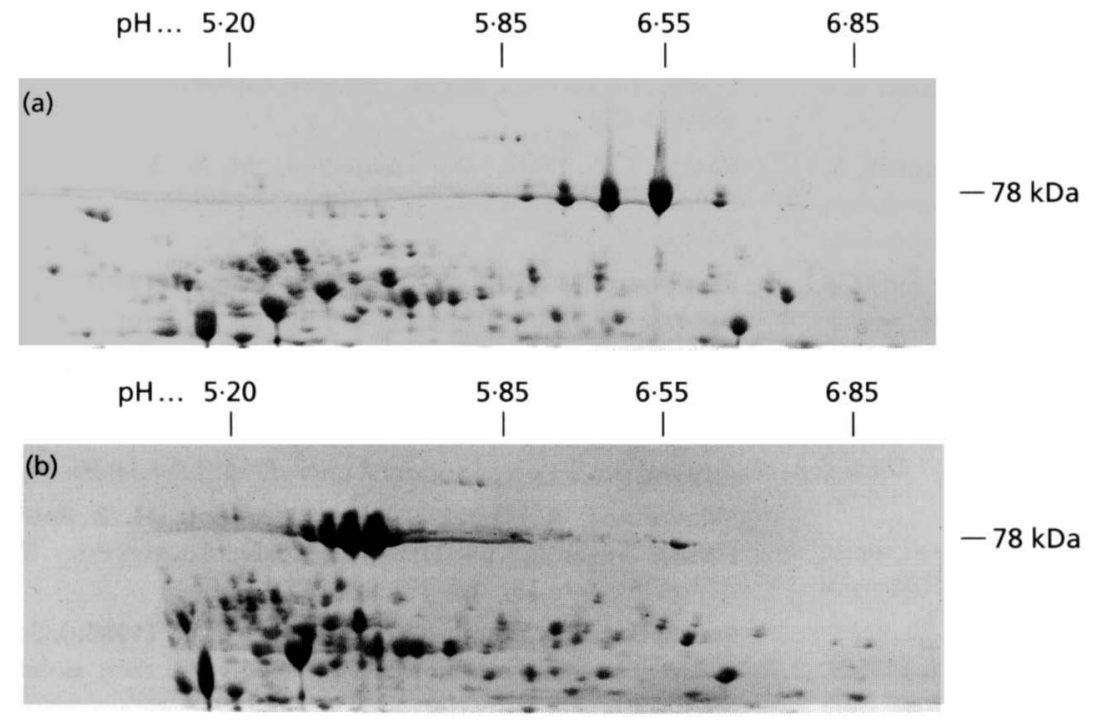

Fig. 8. Two-dimensional gel electrophoresis of $P$. anaerobius strains: (a) P. anaerobius ATCC 27337; (b) AHC5734.

is not known. It is worth noting that of the four species studied so far, $P$. asaccharolyticus, $P$. magnus, $P$. micros and $P$. anaerobius, two species, $P$. asaccharolyticus and $P$. anaerobius, possess an S-layer (Messner \& Buckel, 1988; this study). It is obvious that the S-layer is a more common structure in oral anaerobic bacteria than was previously realized. The results of the present study also demonstrate that the S-layer may remain undetected by the conventional electron microscopic methods usually employed in studies of the ultrastructure of bacteria. Work is now in progress in our laboratory to investigate the role of the S-layers from different oral bacteria, as the outermost structures of the cell, in attachment to host proteins and to other bacteria.

\section{ACKNOWLEDGEMENTS}

We thank Arja Kanervo, National Public Health Institute (Finland), for providing us with the clinical strains of $P$. anaerobius, Heini Torkko, University of Helsinki, for the T- strains of $P$. micros, and Ms Pirkko Leikas-Lazanyi for preparing the samples for electron microscopy. This study was financially supported by the Finnish Dental Society (to A.K. and M.H.), and the Academy of Finland (to K. L.).

\section{REFERENCES}

Absalom, D. R. (1988). The role of bacterial hydrophobicity in infection: bacterial adhesion and phagocytic ingestion. Can $J$ Microbiol 34, 287-298.

Blaser, M. J., Smith, P. F., Repine, J. E. \& Joiner, K. A. (1988). Pathogenesis of Campylobacter fetus infections. Failure of encapsulated Campylobacter fetus to bind C3b explains serum and phagocytosis resistance. J Clin Invest 81, 1434-1444.

Brook, I. (1988). Recovery of anaerobic bacteria from clinical specimens in 12 years at two military hospitals. J Clin Microbiol 26, 1181-1188.

Brook, I. \& Walker, R. I. (1984). Pathogenicity of anaerobic grampositive cocci. Infect Immun 45, 320-324. 
Brook, I., Frazier, E. H. \& Gher, M. E. (1991). Aerobic and anaerobic microbiology of periapical abscess. Oral Microbiol Immunol 6, 123-125.

Carlstedt-Duke, B., Midtvedt, T., Nord, C. E. \& Gustafsson, B. E. (1986). Isolation and characterization of a mucin degrading strain of Peptostreptococcus from rat intestinal tract. Acta Patbol Microbiol Immunol Scand Sect B, Microbiol 94, 293-300.

Cowan, M. M. van der Mei, H. C., Rouxhet, P. G. \& Bussher, H. J. (1992). Physico-chemical and structural properties of the surfaces of Peptostreptococcus micros and Streptococcus mitis as compared to those of mutans streptococci, Streptococus sanguis and Streptococus salivarius. $J$ Gen Microbiol 138, 2707-2714.

van Dalen, P. J., van Steenbergen, T. J. M., Cowan, M. M., Bussher, H. J. \& de Graaff, J. (1993). Description of two morphotypes of Peptostreptococcus micros. Int J Syst Bacteriol 43, 787-793.

Davies, U. M., Leak, A. M. \& Dave, J. (1988). Infection of a prosthetic knee joint with Peptostreptococcus magnus. Ann Rheum Dis 47, 866-868.

Dooley, J. S. G. \& Trust, T. J. (1988). Surface protein composition of Aeromonas bydrophila strains virulent for fish: identification of a surface array protein. J Bacteriol 170, 499-506.

Ezaki, T., Yamamoto, N., Ninomiya, K., Suzuki, S. \& Yabuuchi, E. (1983). Transfer of Peptococcus indolicus, Peptococcus asaccbarolyticus, Peptococcus prevotii, and Peptococcus magnus to genus Peptostreptococcus and proposal of Peptostreptococcus tetradius sp. nov. Int J Syst Bacteriol 33, 683-698.

Haapasalo, M., Kerosuo, E. \& Lounatmaa, K. (1990). Hydrophobicities of human polymorphonuclear leukocytes and oral Bacteroides and Porpbyromonas spp., Wolinella recta and Eubacterium yurii with special reference to bacterial surface structures. Scand $J$ Dent Res 98, 472-481.

Hunter, T. \& Chow, A. W. (1988). Peptostreptococcus magnus septic arthritis - a report and review of the English literature. $J$ Rheumatol 15, 1583-1584.

Kastern, W., Holst, E., Nielsen, E., Sjbbring, U. \& Bjorck, L. (1990). Protein L, a bacterial immunoglobulin-binding protein and possible virulence determinant. Infect Immun 58, 1217-1222.

Kerosuo, E., Haapasalo, M. \& Lounatmaa, K. (1993). Hydrophobic strains of Eubacterium yurii ssp. margaretiae are resistant to nonopsonic phagocytic ingestion. Scand J Dent Res 101, 304-310.

Krepel, C. J., Gohr, C. M., Edmiston, C. E., Jr \& Farmer, S. G. (1991). Anaerobic pathogenesis: collagenase production by Peptostreptococcus magnus and its relationship to site of infection. $J$ Infect Dis 163, 1148-1150.

Laemmli, U. K. (1970). Cleavage of structural proteins during the assembly of the head of bacteriophage T4. Nature 227, 680-685.

Lămmler, C., Alaboudi, A. \& Hildebrand, A. (1989). Characterization of albumin-binding of Peptostreptococcus magnus. Can J Microbiol 35, 614-618.

Lewis, M. A., Lamey, P. J. \& Gibson, J. (1989). Quantitative bacteriology of a case of acute parotitis. Oral Surg Oral Med Oral Pathol 68, 571-575.

Li, N., Hashimoto, Y., Adnan, S., Miura, H., Yamamoto, H. \& Ezaki, T. (1992). Three new species of genus Peptostreptococcus isolated from humans: Peptostreptococcus vaginalis sp. nov., Peptostreptococcus lacrimalis sp. nov., and Peptostreptococcus lactolyticus sp. nov. Int J Syst Bacteriol 42, 602-605.

Lounatmaa, K. (1985). Electron microscopic methods for the study of bacterial surface structures. In Enterobacterial Surface Antigens:
Methods for Molecular Characterization, pp. 243-261. Edited by T. K. Korhonen, E. A. Dawes \& P. H. Mäkelä. Amsterdam: Elsevier.

Lounatmaa, K., Jousimies-Somer, H., Grenman, R. \& Rintala, A. (1988). Crystalline surface layers in anaerobic bacteria isolated from a patient with secretory otitis media and a draining ear. In Crystalline Bacterial Cell Surface Layers, pp. 114-117. Edited by U. B. Sleytr, P. Messner, D. Pum \& M. Sara. Berlin: Springer-Verlag.

Lounatmaa, K., Haapasalo, M., Kerosuo, E. \& Jousimies-Somer, H. (1993). S-layer found on clinical isolates. In Advances in Bacterial Paracrystalline Surface Layers, pp. 33-43. Edited by T. J. Beveridge \& S. F. Koval. New York: Plenum Press.

Messner, P. \& Buckel, W. (1988). The surface layer of Peptostreptococcus asaccharolyticus. Syst Appl Microbiol 10, 226-227.

Messner, P. \& Sleytr, U. B. (1992). Crystalline bacterial cell-surface layers. Adv Microb Pbysiol 33, 214-275.

Panagou, P., Papandreou, L. \& Bouros, D. (1991). Severe anaerobic necrotizing pneumonia complicated by pyopneumothorax and anaerobic monoarthritis due to Peptostreptococcus magnus. Respiration 58, 223-225.

Papasian, C. J., McGregor, D. H., Hodges, G. R. \& Kennedy, J. (1986). Peptostreptococcal vertebral osteomyelitis. J Clin Microbiol 24, 633-635.

Rams, T. E., Feik, D., Listgarten, M. A. \& Slots, J. (1992). Peptostreptococcus micros in human periodontitis. Oral Microbiol Immunol 7, 1-6.

Rosenberg, M., Gutnick, D. \& Rosenberg, E. (1980). Adherence of bacteria to hydrocarbons: a simple method for measuring cellsurface hydrophobicity. FEMS Microbiol Lett 9, 29-33.

Schenkein, H. A., Burmeister, J. A., Koertge, T. E., Brooks, C. N., Best, A. M., Moore, L. V. \& Moore, W. E. (1993). The influence of race and gender on periodontal microflora. J Periodontol 64, 292-296.

Sklavounos, A., Legakis, N. J., loannidou, H. \& Patrikiou, A. (1986). Anaerobic bacteria in dentoalveolar abscesses. Int J Oral Maxillofac Surg 15, 288-291.

Smith, G. L. F., Cumming, C. G. \& Ross, P. W. (1986a). Survival of Gram-positive anaerobic cocci on swabs and their isolation from the mouth and vagina. J Clin Pathol 39, 93-98.

Smith, G. L. F., Cumming, C. G. \& Ross, P. W. (1986b). Analysis of EDTA-soluble cell surface components of $\mathrm{Gram}$-positive anaerobic cocci. J Gen Microbiol 132, 1591-1597.

van Steenbergen, T. J. M. \& de Graaff, J. (1983). Hydrophobicity of black-pigmented Bacteroides strains and the correlation with phagocytosis. Antonie Leeunenboek 49, 605-606.

Sugita, R., Kawamura, S., Icikawa, G., Fujimaki, Y., Oguri, T. \& Deguchi, K. (1982). Microorganisms isolated from peritonsillar abscess and indicated chemotherapy. Arch Otolaryngol 108, 655-658.

Sundqvist, G. (1992). Associations between microbial species in dental root canal infections. Oral Microbiol Immunol 7, 257-262.

Tam, Y.-C. \& Chan, E. C. S. (1983). Phase variation of hyaluronidaseproducing peptostreptococci associated with periodontal disease. $J$ Dent Res 62, 1009-1012.

Tam, Y.-C. \& Chan, E. C. S. (1985). Purification and characterization of hyaluronidase from oral Peptostreptococcus species. Infect Immun 47, 508-513.

Tam, Y.-C., Noble, P. B. \& Chan, E. C. S. (1987). Effects of extracellular products of a presumed gingival pathogen, the bacterium Peptostreptococcus $84 \mathrm{H} 14 \mathrm{~S}$, on cultured human fibroplasts and HeLa cells. Arch Oral Biol 4, 303-305.

Tew, J. G., Marshall, D. R., Moore, W. E. C., Best, A. M., Palcanis, K. G. \& Ranney, R. R. (1985). Serum antibody reactive with 
predominant organisms in the subgingival flora of young adults with generalized severe periodontitis. Infect Immun 48, 303-311.

Topiel, M. S. \& Simon, G. L. (1986). Peptococcaceae bacteremia. Diagn Microbiol Infect Dis 4, 109-117.

Trust, T. J. \& Kay, W. W. (1992). S-layers in bacterial pathogenesis: the tetragonal paracrystalline surface protein array of Aeromonas salmonicida as a special example. In Molecular Recognition in HostParasite Interactions, pp. 65-75. Edited by T. K. Korhonen, T. Hovi \& P. H. Mäkelä. New York: Plenum Press.

Received 14 September 1994; revised 3 January 1995; accepted 19 January 1995. 